\title{
Secondary Production of the Estuarine, Meiobenthic Copepod Microarthridion littorale*
}

\author{
John W. Fleeger ${ }^{1}$ and Margaret A. Palmer ${ }^{2}$ \\ ${ }^{1}$ Department of Zoology, Louisiana State University, Baton Rouge, Louisiana 70803, USA \\ ${ }^{2}$ Belle W. Baruch Institute for Marine Biology and Coastal Research, University of South Carolina, Columbia, South Carolina \\ 29208, USA
}

\begin{abstract}
Secondary production of Microarthridion littorale, an estuarine meiobenthic copepod, was determined in a South Carolina (USA) salt marsh by the use of size-frequency distributions and age specific growth rates. For all individuals production was highest in 1976 during late summer, with a daily production rate of $1.2 \mu \mathrm{g} 10 \mathrm{~cm}^{-2} \mathrm{~d}^{-1}$. In 1978-1979, production for adults was much lower, less than half of the 1976 adult values. An annual production of $0.14 \mathrm{~g} \mathrm{~m}^{-2}$ dry weight is estimated, yielding a production/biomass ratio of $18.0 \mathrm{yr}^{-1}$ in 1976
\end{abstract}

\section{INTRODUCTION}

Empirically derived values of secondary production are helpful in understanding the functional dynamics of ecosystems. Production estimates of the ubiquitous marine meiofauna are particularly important in elucidating their role and energetic importance (Banse and Mosher, 1980). Measurements of production can yield an estimate of the potential meiofaunal calories that may be passed either to higher trophic levels or the decomposer food chain, and aid in determining how meiofaunal production is partitioned from the total energy assimilation of the benthos. Functionally, meiofauna may serve as food for higher trophic levels, as nutrient regenerators and as an aid an facilitating detritus transfer to macrofauna (Coull and Bell, 1979).

Perhaps the ideal way to determine production for a species is to identify a cohort and follow, over time, changes in density and biomass for that cohort. Some meiofauna species do produce only 1 or 2 generations per year (Barnett, 1970; Feller, 1980) making cohort recognition possible. However, in many other species, especially in warm water habitats, generations widely overlap making cohort identification unlikely. Gerlach (1971) estimates that the average meiofauna species produces 9 generations each year. When cohorts can-

- Contribution No. 420 from the Belle W. Baruch Institute for Marine Biology and Coastal Research

(C) Inter-Research/Printed in F. R. Germany not be followed from field collections, estimation of production requires painstaking analysis of population sizes and recruitment gathered over short time intervals, coupled with the use of size specific growth rates obtained from laboratory cultures (Mann, 1976; Warwick, 1980). Laboratory rearing of meiofauna has proven difficult (Palmer and Coull, 1980). Consequently, the only published account of empirically derived meiofauna production values is the report by Banse and Mosher (1980) of Feller's (1977) work with the meiobenthic harpacticoid Huntemannia jadensis in Puget Sound, USA.

We report here on production estimates of another meiobenthic copepod Microarthridion littorale (Poppe), which is world-wide distributed, being especially common in salt marshes of the southeastern US and Gulf of Mexico (Hiegel, 1969; Coull et al., 1979). Microarthridion littorale comprises from $10-38 \%$ of the copepod fauna of South Carolina intertidal marshes (Bell, 1979; Fleeger, 1980), being the dominant muddwelling estuarine copepod. As many as 12 overlapping generations per year with prolonged reproductive activity occur intertidally (Fleeger, 1979; Palmer, 1980). Because of its dominance among mud-dwelling copepods in marsh habitats, where copepods typically are the second most abundant meiofaunal taxon after nematodes, and because of its widespread distribution, $M$. littorale is an appropriate and representative meiobenthic species for production studies. 


\section{MATERIALS AND METHODS}

The Microarthridion littorale population in a low marsh intertidal site in North Inlet Estuary, South Carolina (USA) was studied during 1976 by Fleeger, and 1978-1979 by Palmer. The site is characterized by soft, fine sediment ( $80 \%$ silt and clay) and by the presence of numerous culms of healthy Spartina alterniflora. Consult Fleeger (1979) and Palmer (1980) for more complete details of the sampling site, sampling techniques, and original census data.

Quantitative collections were made by hand coring at low tide with $2.54 \mathrm{~cm}$ diameter core tubes. A total of 20 collections from 1976 were utilized in calculations of production. Total body length, excluding rostrum and candal rami, was measured from each collection on at least 200 individuals including nauplii, copepodites, and adults. Collections from 1976 were not equally spaced over time, but were concentrated during early spring, mid-summer, and early late fall so that short interval sampling (5-10 d) could be made when populations were growing or changing rapidly. A tatal of 25 collections were made at approximately $15 \mathrm{~d}$ intervals in 1978-1979. In 1978-1979, only the lengths of adult Microarthridion littorale were measured. Production values are reported here for the entire population for parts of 1976, but only for the adults in 1978-1979.

A length weight relationship of copepodite and adult Microarthridion littorale was determined with the aid of a Cahn Electrobalance. Frozen specimens of $M$. littorale were sorted in various size groups and placed into small, preweighed aluminum pans. Pans, each containing from 15-70 individuals, were dried to constant weight at $95^{\circ} \mathrm{C}$, and re-weighed. One group of 75 nauplii averaging $180 \mu \mathrm{m}$ in length was also weighed, however, nauplii values were not used in the length weight regression. An attempt was made to weigh smaller nauplii as well; however, too few were available to provide adequate numbers for accurate measurement.

Crisp's (1971) method 3A, production for stocks with recruitment, age classes not separable, was used for production calculations. Specifically,

$$
P=\Sigma \Sigma f_{j} G_{2} \bar{W}_{1} \Delta t
$$

where $P=$ production; $f_{1}=$ number of individuals per unit surface area of Size group $i$ present during Period $\Delta t_{i} G_{i}=$ specific growth rate of the size group $\bar{w}_{1}=$ mean weight of the size group. Growth rates $\left(G_{2}\right)$ were determined independent of field sampling (see below). Six size classes were established, 3 approximating the 6 naupliar stages and 3 approximating the 5 copepodite stages and the adult. Weights of individuals were determined from their lengths by the use of the length weight regression for Microarthridion littorale, and the size class mean weights $\left(\bar{w}_{1}\right)$ and variances for each collection were calculated. Population density estimates from field collections were averaged between each collection yielding a value of $f$ for each size class. Egg weights of gravid females were not estimated at any time.

The growth data of Palmer and Coull (1980), who determined time from egg to adult stage of Microarthridion littorale at different temperatures, were used to calculate size specific growth rates. To calculate a growth rate, growth by the Bertalanffy equation was assumed:

$$
l_{t}=L_{\infty}-\left(L_{\infty}-L_{0}\right) e^{-K t}
$$

where $L_{0}$ and $L_{\infty}=$ constants representing length at zero age and maximum age respectively; $l=$ length at time $t ; K=$ a constant. $K$ was estimated graphically by the method of Ricklefs (1967) for each temperature of Palmer and Coull's (1980) data. This growth constant was then regressed with temperature, and a predicted $K$ at each average South Carolina field temperature was calculated. Crisp (1971, pp. 241-243) has shown that the weight specific growth rate ( $G$ ) may be given by

$$
G=b K\left(L_{\infty}-I\right) / l
$$

where $b=$ weight/length regression coefficient and $l$ $=$ mean length for a size class under consideration. Growth rates ( $G$ ) were determined for each size class at each collection interval by this method.

Confidence limits for the estimates of production were determined for 1976 by the methods of Chapman (1967). This method uses estimates of the variation in $f_{11}$ $w_{j}$, and $G_{j}$ to find the variation of the product of these terms. Several sources of error are included in the production variability estimates. These include variance in estimates of density, $V(N)$, for a size group on a collection date (determined by calculation of variance among replicate samples), variance in mean weight (measured as variance among all individual weights of a size class on a sampling date) and variance in growth rate determination (measured as variance in individual growth; see Palmer and Coull, 1980). Confidence limits for 1978-1979 production values were not determined because density estimate variability among replicate samples was not available from those data.

\section{RESULTS AND DISCUSSION}

The length weight regression for Microarthridion littorale (Fig. 1) was determined by weighing individuals of mean lengths of from $220 \mu \mathrm{m}$ (Stage 1 and 


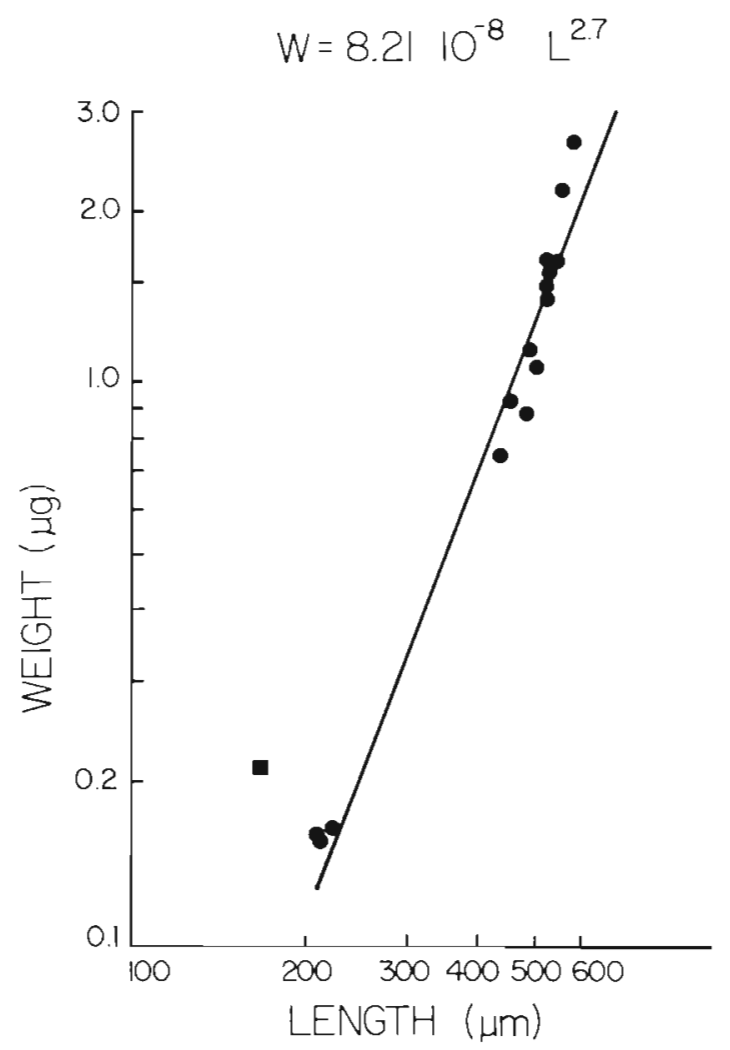

Fig. 1 Microarthridion littorale. Length weight relationship for adults and copepodites. Each circle represents the average length and weight of at least 15 individuals. Square: 1 determination for nauplii

Stage 2 copepodites) to $540 \mu \mathrm{m}$ (sexually mature individuals). The calculated least squares expression, excluding nauplii, is in the form of the allometric equation, and is $W=8.21 \cdot 10^{-8} \cdot L^{2.7}$, where $W=$ weight in $\mu \mathrm{g}$ dry weight; $L=$ body length in $\mu \mathrm{m}$. The standard error of $b$, the regression slope, is 0.137 ; the regression is significantly different from 0 at the 0.001 level. The values found for $M$. littorale agree closely with the linear length weight regression for several harpacticoid species found by Goodman (1980).

Larger nauplii were approximately equal to, or slightly heavier than, the smallest copepodites (Fig. 1). Similar results were obtained in the few instances where length weight relationships for nauplii, as well as copepodites and adults, were calculated (Durbin and Durbin, 1978; Landry, 1978). In fact, the length weight relationship for nauplii should differ from adults due to the major changes in body shape which occur in the molt from the rounded nauplii to the more elongate copepodite. Due to the difficulty in weighing smaller nauplii, the copepodite adult regression was extrapolated for nauplii weight determinations. Therefore, the use of this regression will underestimate naupliar weights because the nauplii are shorter per unit of body weight. Thus, biomass values for all naupliar weights are conservative estimates.

In 1976, dry weight production for all individuals was determined for 3 time periods; 15 February -21 March, 13 July - 10 August and 7 September - 30 November (Table 1). Total production for the entire $143 \mathrm{~d}$ under investigation amounted to $97.8 \mu \mathrm{g} 10 \mathrm{~cm}^{-2}$ Production on a daily basis was lowest during the early spring, $0.068 \mu \mathrm{g} \quad 10 \mathrm{~cm}^{-2} \mathrm{~d}^{-1}$, when population densities and recruitment were low. Production was much higher in the late summer and early fall $(1.2 \mu \mathrm{g}$ $\left.10 \mathrm{~cm}^{-2} \mathrm{~d}^{-1}\right)$, and reached peak at $2.0 \mu \mathrm{g} \cdot 10 \mathrm{~cm}^{-2} \mathrm{~d}^{-1}$ during early September when densities were also at a maximum. Weekly production rates declined through the fall as temperatures and densities declined. Variability was highest during July - August when $95 \%$ confidence limits exceeded $100 \%$ of the production estimate (Table 1). Generally, more confidence could be placed in production estimates during the fall months when density estimates were most reliable (Fleeger, 1979). Production trends for adults mirrored trends for the entire population.

Generally, production of Microarthridion littorale correlated well with population density. Given the 1976 seasonal pattern of $M$. littorale abundance (winter and spring low densities, $<100 \mathrm{~cm}^{-2}$, to sustained high densities from July - October, $>300$ $\left.10 \mathrm{~cm}^{-2}\right)$, the intensive collections during $13 \mathrm{July}-10$ August and 7 September - 30 November measured a large portion of the annual production in 1976. An estimate of the total annual production would be of great interest. To estimate annual production, we derived empirical values of daily $\mathrm{P} / \overline{\mathrm{B}}$ (production to biomass) ratio for the intensive collections of February - March, July - August and September - November by the use of the production data of Table 1 and from field derived average biomass values for the same time periods. $\mathrm{P} / \overline{\mathrm{B}} \mathrm{d}^{-1}$ were $0.045,0.103$ and 0.058 for February - March, July - August and September - November, respectively. We used these values to estimate production between intensive collections. Production was correlated with density, and densities of $M$. littorale changed gradually through much of the year; thus change in $\mathrm{P} / \overline{\mathrm{B}}$ ratios were probably not abrupt but gradual between intensive collections. The $\mathrm{P} / \overline{\mathrm{B}} \mathrm{d}^{-1}$ value of 0.045 (calculated from February - March) was used for the 22 March - 12 July interval, and a value of 0.081 (interpolated between July - August and September - November) was used for the 11 August -6 September interval. Production during the winter months of December and 1 January - 14 February was assumed to be nil. The $\mathrm{P} / \overline{\mathrm{B}} \mathrm{d}^{-1}$ ratio for each interval was multiplied by the average biomass and the number of days to arrive at a production value for the interval. 
Table 1. Microarthridion littorale. Production (P) by size class for periods of $1976.95 \%$ confidence limits expressed as a $\%$ of production estimate

\begin{tabular}{|c|c|c|c|c|c|c|}
\hline \multirow[t]{2}{*}{ Time period } & \multicolumn{6}{|c|}{ Size class $(\mu \mathrm{m})$} \\
\hline & $64-86$ & $87-128$ & $128-179$ & $180-280$ & $281-440$ & $>440$ \\
\hline 15 Feb - 22 Feb & 0.008 & 0.023 & 0.001 & 0.007 & 0.008 & 0.060 \\
\hline 22 Feb - 29 Feb & 0.041 & 0.084 & 0.043 & 0.014 & 0.028 & 0.115 \\
\hline $29 \mathrm{Feb}-7 \mathrm{Mar}$ & 0.056 & 0.132 & 0.078 & 0.037 & 0.098 & 0.141 \\
\hline $7 \mathrm{Mar}-14 \mathrm{Mar}$ & 0.024 & 0.125 & 0.106 & 0.064 & 0.163 & 0.146 \\
\hline $14 \mathrm{Mar}-21 \mathrm{Mar}$ & $\underline{0.022}$ & $\underline{0.104}$ & 0.126 & $\underline{0.107}$ & $\underline{0.179}$ & $\underline{0.265}$ \\
\hline Total by size class & 0.151 & 0.468 & 0.354 & 0.228 & 0.476 & 0.627 \\
\hline Variance $(P)$ & 0.059 & 0.134 & 0.100 & 0.066 & 0.248 & 0.213 \\
\hline \multirow{2}{*}{\multicolumn{2}{|c|}{$\begin{array}{l}\text { Total production for entire time period } \\
95 \% \text { Confidence limit }\end{array}$}} & \multirow{2}{*}{\multicolumn{2}{|c|}{$\begin{array}{l}2.3 \mu \mathrm{g} 10 \mathrm{~cm}^{-2} \\
87.4 \%\end{array}$}} & & & \\
\hline & & & & & & \\
\hline $13 \mathrm{Jul}-20 \mathrm{Jul}$ & 0.395 & 1.246 & 0.804 & 0.552 & 1.320 & 1.883 \\
\hline $20 \mathrm{Jull}-29 \mathrm{Jul}$ & 0.820 & 2.224 & 4.806 & 1.010 & 2.282 & 3.325 \\
\hline 29 Jul - 10 Aug & 1.017 & 2.578 & 1.577 & 1.643 & 3.011 & 3.862 \\
\hline Total by size class & 2.232 & 6.048 & 7.187 & 3.205 & 6.613 & 9.070 \\
\hline Variance $(\mathrm{P})$ & 0.484 & 1.450 & 0.860 & 0.802 & 1.936 & 3.946 \\
\hline \multirow{2}{*}{\multicolumn{2}{|c|}{$\begin{array}{l}\text { Total production for entire time period } \\
95 \% \text { Confidence limit }\end{array}$}} & \multirow{2}{*}{\multicolumn{2}{|c|}{$\begin{array}{l}34.4 \mu \mathrm{g} 10 \mathrm{~cm}^{-2} \\
128.8 \%\end{array}$}} & & & \\
\hline & & & & & & \\
\hline 7 Sep - 16 Sep & 1.610 & 4.139 & 2.321 & 2.703 & 2.619 & 4.166 \\
\hline 16 Sep -21 Sep & 0.806 & 1.363 & 0.550 & 1.340 & 2.126 & 2.559 \\
\hline 21 Sep -28 Sep & 0.756 & 0.875 & 0.183 & 1.042 & 2.715 & 3.006 \\
\hline $28 \mathrm{Sep}-7 \mathrm{Oct}$ & 0.701 & 0.845 & 0.277 & 0.483 & 1.942 & 3.516 \\
\hline 7 Oct -16 Oct & 0.597 & 0.715 & 0.330 & 0.662 & 1.667 & 2.721 \\
\hline $16 \mathrm{Oct}-30 \mathrm{Oct}$ & 0.384 & 0.526 & 0.262 & 0.581 & 2.128 & 3.000 \\
\hline $30 \mathrm{Oct}-9 \mathrm{Nov}$ & 0.139 & 0.177 & 0.096 & 0.063 & 0.668 & 1.300 \\
\hline $9 \mathrm{Nov}-21 \mathrm{Nov}$ & 0.101 & 0.177 & 0.082 & 0.012 & 0.454 & 0.707 \\
\hline 21 Nov -30 Nov & 0.019 & 0.095 & $\underline{0.027}$ & 0.078 & 0.266 & 0.380 \\
\hline Total by size class & 5.113 & 8.912 & 4.128 & 6.964 & 14.585 & 21.355 \\
\hline Variance $(\mathrm{P})$ & 1.340 & 4.450 & 1.100 & 2.250 & 5.290 & 17.067 \\
\hline \multirow{2}{*}{\multicolumn{2}{|c|}{$\begin{array}{l}\text { Total production for entire time period } \\
95 \% \text { Confidence limit }\end{array}$}} & \multirow{2}{*}{\multicolumn{2}{|c|}{$\begin{array}{l}61.1 \mu \mathrm{g} 10 \mathrm{~cm}^{-2} \\
65.4 \%\end{array}$}} & & & \\
\hline & & & & & & \\
\hline
\end{tabular}

These calculations yield a production value of $11 \mu \mathrm{g}$ $10 \mathrm{~cm}^{-2}$ from 22 March - 12 July and a value of $33 \mu \mathrm{g}$ $10 \mathrm{~cm}^{-2}$ from 11 August -6 September. When these values are summed with the empirical estimates of Table 1, total annual production for Microarthridion littorale was $0.14 \mathrm{~g} \mathrm{~m}^{-2}$, yielding an annual $\mathrm{P} / \overline{\mathrm{B}}$ ratio of $18.0 \mathrm{y}^{-1}$

Production for adult Microarthridion littorale (> $440 \mu \mathrm{m}$ ) for the year beginning in July, 1978, was lower than the adult 1976 value (Tables 1 and 2). When comparing years, adult production on a weekly basis was quite similar during the spring months, however, production during the fall of 1978 was not sustained at as high a rate for as long compared to 1976 . The sustained peak in population density and biomass observerd in 1976 did not occur in 1978. Total population densities averaged $42310 \mathrm{~cm}^{-2}$ during July September, 1976, compared to $13010 \mathrm{~cm}^{-2}$ during the same time in 1978 (Fleeger, 1979; Palmer, 1980). Production of adults for the year beginning in July, 1978, totalled only $14.4 \mu \mathrm{g} 10 \mathrm{~cm}^{-2}$, compared to $31.0 \mu \mathrm{g}$
$10 \mathrm{~cm}^{-2}$ in the $143 \mathrm{~d}$ under investigation in 1976 . Thus, $M$. littorale displayed high variation in production between the 2 years under investigation with adult production in 1976 more than double that for adults in 1978-1979. Large variability from year to year in meiofauna density is not uncommon (Coull and Fleeger, 1977), and has been reported specifically for M. littorale by Bell (1979). The cause of this variation is unknown; further quantification of temporal and spatial variation of meiofauna production is certainly worthy of future investigation, and necessary to help evaluate the ecological role of meiofauna. Ratios of production to biomass may vary greatly over space and time.

Several authors have speculated on the average annual $\mathrm{P} / \overline{\mathrm{B}}$ ratio for meiofauna, with most estimates at 9-10 $\mathrm{y}^{-1}$ (McIntyre, 1964; Gerlach, 1971). Such values have achieved theoretical (Banse and Mosher, 1980) as well as practical importance. Annual $P / \bar{B}$ values are regularly used in collaboration with standing crop biomass to estimate meiofauna productivity in carbon 
Table 2. Microarthridion littorale. Production of adults for 1978-1979

\begin{tabular}{|c|c|c|c|c|c|}
\hline & $\begin{array}{l}\Delta t \\
\text { (d) }\end{array}$ & $\begin{array}{l}\text { Average frequency } \\
\qquad\left(10 \mathrm{~cm}^{-2}\right)\end{array}$ & 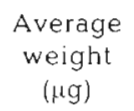 & $\begin{array}{c}\text { Growth } \\
\text { rate } \\
\left(\mathrm{d}^{-1}\right)\end{array}$ & $\begin{array}{r}\text { Production } \\
\left(\mu \mathrm{g} 10 \mathrm{~cm}^{-2}\right)\end{array}$ \\
\hline $9 \mathrm{Jul}-17 \mathrm{Jul}$ & 10 & 41.0 & 0.120 & 0.028 & 1.373 \\
\hline $17 \mathrm{Jul}-28 \mathrm{Jul}$ & 9 & 45.0 & 0.123 & 0.032 & 1.597 \\
\hline $28 \mathrm{Jul}-3 \mathrm{Aug}$ & 6 & 34.5 & 0.125 & 0.033 & 0.852 \\
\hline 3 Aug -18 Aug & 15 & 8.0 & 0.125 & 0.030 & 0.450 \\
\hline 18 Aug - 1 Sep & 15 & 7.5 & 0.108 & 0.030 & 0.366 \\
\hline 1 Sep -12 Sep & 11 & 13.0 & 0.110 & 0.027 & 0.424 \\
\hline $12 \mathrm{Sep}-23 \mathrm{Sep}$ & 11 & 18.0 & 0.107 & 0.026 & 0.551 \\
\hline $23 \mathrm{Sep}-28 \mathrm{Sep}$ & 5 & 23.5 & 0.134 & 0.026 & 0.410 \\
\hline $28 \mathrm{Sep}-12 \mathrm{Oct}$ & 14 & 32.0 & 0.103 & 0.026 & 1.196 \\
\hline 12 Oct -26 Oct & 14 & 29.0 & 0.152 & 0.024 & 1.477 \\
\hline 26 Oct -12 Nov & 17 & 23.0 & 0.153 & 0.015 & 0.899 \\
\hline 12 Nov -27 Nov & 15 & 20.0 & 0.177 & 0.011 & 0.585 \\
\hline 27 Nov $-17 \mathrm{Dec}$ & 20 & 14.5 & 0.166 & 0.008 & 0.386 \\
\hline 17 Dec - 2 Jan & 16 & 10.0 & 0.159 & 0.005 & 0.127 \\
\hline 2 Jan -18 Jan & 16 & 10.5 & 0.158 & 0.005 & 0.133 \\
\hline $18 \mathrm{Jan}-14 \mathrm{Feb}$ & 27 & 10.5 & 0.151 & 0.005 & 0.214 \\
\hline 14 Feb -11 Mar & 25 & 6.0 & 0.178 & 0.010 & 0.267 \\
\hline $11 \mathrm{Mar}-28 \mathrm{Mar}$ & 17 & 5.5 & 0.184 & 0.013 & 0.224 \\
\hline $28 \mathrm{Mar}-16 \mathrm{Apr}$ & 19 & 5.5 & 0.180 & 0.016 & 0.301 \\
\hline $16 \mathrm{Apr}$ - 7 May & 22 & 5.5 & 0.176 & 0.020 & 0.448 \\
\hline 7 May-20 May & 14 & 7.5 & 0.161 & 0.025 & 0.424 \\
\hline 20 May-10 Jun & 21 & 9.5 & 0.131 & 0.025 & 0.651 \\
\hline \multirow[t]{2}{*}{$10 \mathrm{Jun}-1 \mathrm{Jul}$} & 21 & 15.5 & 0.119 & 0.028 & 1.083 \\
\hline & & & & & $1 \overline{4.4}$ \\
\hline
\end{tabular}

or energy models of marine ecosystems (Day et al., 1973; Rosenberg et al., 1977). The present study shows that, at least in warm waters, the annual $P / \bar{B}$ ratio of 9 $\mathrm{yI}^{-1}$ would underestimate production for Microarthridion littorale, and the possibility exists that meiofauna production is underestimated in various models. No comparative data exists for any warm water meiofauna species and certainly generalizations based on one species should be taken with caution. For example, we have already shown that temporal variability exists for production in $M$. littorale. A surface-dweller such as M. littorale in the upper few $\mathrm{mm}$, may be under considerable predation pressure as shown by life history data (Fleeger, 1979) and field experimentation (Bell, 1980). Further interpretation of $\mathrm{P} / \overline{\mathrm{B}}$ ratios in meiofauna awaits the determination of temporal and spatial variation of production for a wider cross section of the meiofauna community.

Acknowledgements. We wish to thank R. Feller, S. Bell, and J. Grant for critical review of this manuscript and its earlier versions. This research was supported by the Oceangraphic Section, National Science Foundation, Grant No. OCE-8007968 (B.C. Coull, Principal Investigator) and by a LSU Council on Research Faculty Research Grant to JWF.

\section{LITERATURE CITED}

Banse, K., Mosher, S. (1980). Adult body mass and annual production/biomass relationships of field populations. Ecol. Monogr. 50: 355-379

Barnett, P. R. O. (1970). The life cycles of two species of Platychelipus Brady (Harpacticoida) on an intertidal mudflat. Int. Revue ges. Hydrobiol. 55: 169-195

Bell, S. S. (1979). Short- and long-term variation in a high marsh meiofauna community. Estuar. coast. mar. Sci. 9: $331-350$

Bell, S. S. (1980). Meiofauna-macrofauna interactions in a high salt marsh habitat. Ecol. Monogr. 50: 487-505

Chapman, D. W. (1967). Production in fish populations. In: Gerking, S. D. (ed.) The biological basis of freshwater fish production. Wiley, New York, pp. 3-30

Coull, B. C., Bell, S. S. (1979). Perspectives in marine meiofauna ecology. In: Livingston, R. J. (ed.) Ecological processes in coastal marine ecosystems. Plenum, New York, pp. 189-216

Coull, B. C., Bell, S. S., Savory, A. M., Dudley, B. W. (1979) Zonation of meiobenthic copepods in a Southeastern United States salt marsh. Estuar. coast. mar. Sci. 9: 181-188

Coull, B. C., Fleeger, J. W. (1977). Long-term variation and community dynamics of meiobenthic copepods. Ecology 58: $1136-1143$

Crisp, D. J. (1971). Energy flow measurements. In: Holme, N. A., McIntyre, A. D. (eds.) Methods for the study of marine benthos. IBP Handbook 16. Blackwell, Oxford, pp. $197-279$

Day, J. W., Smith, W. G., Wagner, P. R., Stowe, W. C. (1973). Community structure and carbon budget of a sait marsh 
and shallow bay estuarine system in Louisiana. Publ. No LSU - SG - 73-04, Louisiana State, University

Durbin, E. G., Durbin, A. G. (1978). Length and weight relationships of Acartia clausi from Narragansett Bay, R.I. Limnol. Oceanogr. 23: 958-969

Feller, R. J. (1977). Life history and production of meiobenthic harpacticoid copepods in Puget Sound. Dissertation, University Washington, Seattle

Feller, R. J. (1980) Quantitative cohort analysis of a sanddwelling meiobenthic harpaciticoid copepod. Estuar. coast. mar. Sci. 11: 459-476

Fleeger, J. W. (1979). Population dynamics of three estuarine meiobenthic harpacticoids (Copepoda) in South Carolina Mar. Biol. 52: 147-156

Fleeger, J. W. (1980). Community structure of an estuarine meiobenthic copepod assemblage. Estuar. coast. mar. Sci. 10: $107-118$

Gerlach, S. A. (1971). On the importance of marine meiofauna for benthos communities. Oecologia (Berl.) 6: 176-190

Goodman, K. S. (1980). The estimation of individual dry weight and standing crop of harpacticoid copepods. Hydrobiologica 72: 253-259

Hiegel, M. H. (1969). A survey of the bottom dwelling copepods of a Louisiana marsh lake. M.S. thesis, Louisiana State University, Baton Rouge
Landry, M. R. (1978). Population dynamics and production of a planktonic marine copepod, Acartia clausii, in a small temperate lagoon on San Juan Island. Washington. Int. Revue ges. Hydrobiol. 63: 77-119

Mann, K. H. (1976). Production on the bottom of the sea. In Cushing, D. H., Walsh, J. J. (eds.) The ecology of the seas. Saunders, New York, pp. 225-250

McIntyre, A. D. (1964). Ecology of marine meiobenthos. Biol. Rev. 44: 245-190

Palmer, M. A. (1980). Variation in life history patterns between intertidal and subtidal populations of Microarthridion littorale. Mar. Biol. 60: 159-165

Palmer, M. A., Coull, B. C. (1980). The prediction of development rate and the effect of temperature for the meiobenthic copepod, Microarthridion littorale (Poppe). J. exp mar. Biol. Ecol. 48: 73-83

Ricklefs, R. E. (1967). A graphical method of fitting equations to growth curves. Ecology 48: 978-983

Rosenberg, R., Olsson, I., Olundh, E. (1977). Energy flow model of an oxygen deficient estuary on the Swedish west coast. Mar. Biol. 42: 99-107

Warwick, R. M. (1980). Population dynamics and secondary production of benthos. In: Tenore, K. R., Coull, B. C. (eds.) Marine benthic dynamics. University of South Carolina Press, Columbia, pp. 1-24 